\title{
The Study of In-Migration between Provinces in Indonesia by Panel Data Regression
}

\author{
Asmadhini Handayani Rahmah \\ Department of Statistics Universitas Islam Indonesia, Jalan Kaliurang Km 14,5 Sleman Yogyakarta \\ asmadhini@uii.ac.id
}

\begin{abstract}
Indonesia has 34 provinces. There are many peoples spread out across Indonesia and the vast area owned makes Indonesia become one of the biggest 4 (four) most population country in the world. However, the population density is not spread evenly in Indonesia. This has become interesting to be observed how the distribution of population in Indonesia by using variable in-migration as a dependent variable that is assumed to be influenced by four (4) independent variables. Those independent variables are the Gross Domestic Product (GDP), the Regional Minimum Wage, Unemployment Rate (TPT) and Labor Force Participation Rate (LFPR). Data is collected from www.BPS.go.id . The analysistool used panel data regression, denote a data type is a combination of time series data (time series) and cross section data. The best selected model used in this research is Fixed Effect model to obtain 33 models for 33 provinces. The variables that influence the inmigration is the Open unemployment rate (TPT), which has a negative correlation to in-migration, while the Labor Force Participation Rate (LFPR) has a positive correlation.
\end{abstract}

Keywords: In-Migration, Gross Domestic Product (GDP), the Regional Minimum Wage, Unemployment Rate (TPT), Labor Force Participation Rate (LFPR), Panel Data Regression, Fixed Effect model.

\footnotetext{
ABSTRAK

Indonesia terbagi menjadi 34 provinsi. Banyaknya penduduk yang tersebar di Indonesia dan luasnya wilayah yang dimiliki membuat Indonesia menjadi salah satu negara dengan jumlah penduduk nomor 4 (empat) terbesar di dunia. Hal ini disebut dengan kepadatan penduduk. Namun, kepadatan penduduk tidak tersebar secara merata di Indonesia. Hal inilah yang menjadi menarik untuk diteliti, bagaimanakah sebaran penduduk di Indonesia dilihat dengan menggunakan variabel migrasi masuk sebagai variabel terikat yang di duga dipengaruhi oleh 4 variabel bebas. Keempat variable bebas tersebut yaitu Produk Domestik Regional Bruto (PDRB), Upah Minimum Regional (UMR), Tingkat Pengangguran Terbuka (TPT) dan Tingkat Partisipasi Angkatan Kerja (TPAK). Pengambilan data dilakukan melalui www.BPS.go.id. Alat analisis yang digunakan adalah regresi data panel yang merupakan regresi yang jenis datanya merupakan gabungan antara data runtun waktu (time series) dan The Study of In-Migration between Provinces in Indonesia by Panel Data Regression (Asmadhini Handayani Rahmah) 
data silang (cross section). Model yang terpilih paling baik digunakan pada penelitian ini adalah Fixed Effect sehingga didapatkan 33 model untuk 33 provinsi. Variabel yang berpengaruh terhadap migrasi masuk adalah Tingkat pengangguran Terbuka (TPT) yang memiliki korelasi negatif terhadap migrasi masuk, sedangkan Tingkat Partisipasi Angkatan Kerja (TPAK) memiliki korelasi positif.

Kata - kata kunci: Migrasi Masuk, Produk Domestik Regional Bruto (PDRB), Upah Minimum Regional (UMR), Tingkat Pengangguran Terbuka (TPT), Tingkat Partisipasi Angkatan Kerja (TPAK), Regresi Data Panel, model Fixed Effect.

\section{Pendahuluan}

Indonesia merupakan negara yang terdiri dari banyak pulau, sering disebut juga sebagai negara kepulauan. Saat ini, Indonesia terbagi menjadi 34 provinsi. Banyaknya penduduk yang tersebar di Indonesia dan luasnya wilayah yang dimiliki membuat Indonesia menjadi salah satu negara dengan jumlah penduduk nomor 4 (empat) terbesar di dunia setelah China, India dan Amerika Serikat. Berdasarkan data Badan Pusat Statistik (2016), Jumlah penduduk Indonesia saat ini diperkirakan sebesar 255 juta jiwa dengan laju pertumbuhan penduduk sebesar 1,4 \% per tahunnya yang artinya ada kemungkinan pertambahan penduduk sebesar 3,5 juta setiap tahunnya. Hal ini tergambar dengan jumlah kepadatan penduduk yang terbesar adalah di provinsi DKI Jakarta, dengan jumlah 15.173 jiwa $/ \mathrm{km}^{2}$, namun kepadatan penduduk ini tidak merata di seluruh provinsi di Indonesia. Semakin padatnya penduduk di suatu daerah dan persentase laju pertumbuhan penduduk ini mengakibatkan lapangan kerja pun harus tersedia setiap tahunnya. Hal inilah yang menjadi salah satu alasan seseorang untuk melakukan perpindahan tempat yang sering disebut sebagai migrasi.

Selain kelahiran dan kematian, migrasi merupakan salah satu faktor yang meningkatkan pertumbuhan penduduk di suatu provinsi. Peninjauan migrasi secara regional sangat penting untuk ditelaah secara khusus mengingat adanya kepadatan dan distribusi penduduk yang tidak merata, adanya faktor-faktor pendorong dan penarik bagi orang-orang untuk melakukan migrasi, serta adanya desentralisasi dalam pembangunan. Migrasi penduduk terjadi karena diarahkan atau atas kebijakan tertentu yang diatur oleh pemerintah, namun lebih banyak karena spontan atau keinginan dari individu masyarakat itu sendiri.

$\begin{array}{llr}\text { Migrasi } & \text { menjadi sangat menarik } \\ \text { dikarenakan } & \text { menurut teori yang } \\ \text { dikemukakan } & \text { para ekonom, bahwa }\end{array}$


seharusnya migrasi penduduk membawa pengaruh positif terhadap daerah tujuan migrasi tersebut, namun yang terjadi pada kenyataannya adalah berkebalikan. Di Indonesia, karena pola migrasi tidak terkontrol ke kota-kota besar, mengakibatkan meningkatnya pencemaran lingkungan hidup, kemacetan lalu lintas, bertambah banyaknya pemukiman kumuh dan juga jumlah pengangguran.

Menurut Simanulang dkk. (2011), secara umum masyarakat yang berada pada daerah dengan kondisi perekonomian relatif rendah, cenderung bermigrasi ke daerah dengan kondisi perekonomian lebih tinggi. Sehingga disimpulkan bahwa daya tarik suatu daerah adalah faktor penunjang ekonomi yang baik seperti tersedianya lapangan pekerjaan, tingginya upah dan harapan untuk mendapatkan penghidupan yang lebih layak didaerah tujuan.

Menurut Bălă and Prada (2014) Fenomena migrasi dan konsumsi masyarakat merupakan bagian penting dalam makro ekonomi oleh karena itu dengan menggunakan regresi data panel diteliiti hubungan timbal balik antara migrasi dan konsumsi rumah tangga masyarakat 26 negara di Eropa pada periode 1996-2011. Migrasi dalam penelitian ini dibagi menjadi dua, yaitu emigrasi dan imigrasi. Hasil dari penelitian ini adalah terjadi hubungan negatif untuk kedua hubungan timbal balik yang dilakukan. Tingkat migrasi penduduk memiliki dampak negatif terhadap konsumsi rumah tangga, dalam hal ini yang memiiki dampak paling besar adalah imigrasi. Dapat disimpulkan bahwa dengan tingginya tingkat imigrasi, maka pendapatan asli penduduk negara tersebut menurun dikarenakan pendapatan negara tersebut diserap oleh para imigran, dan akhirnya menyebabkan konsumsi rumah tangga pun menurun. Begitu juga sebaliknya yang terjadi pada hubungan negatif dari konsumsi terhadap tingkat migrasi, didapatkan jika tingkat konsumsi suatu negara meningkat maka negara tersebut akan memilih lebih banyak emigran dibandingkan imigran.

Menurut Jennissen (2003), pada penelitiannya terhadap faktor-faktor ekonomi yang mempengaruhi migrasi neto internasional di Eropa Barat. Didapatkan hasil bahwa Produk Domestik Bruto memiliki pengaruh positif terhadap arus masuknya penduduk ke suatu negara di wilayah Eropa Barat. Sedangkan tingkat pengangguran memiliki pengaruh negatif, hal ini dibenarkan bahwa, keinginan seseorang untuk berpindah ke suatu wilayah didasarkan keinginan untuk mencari lapangan pekerjaan yang baru. Hal ini 
Dalam penelitian ini, migrasi yang diteliti adalah migrasi masuk dalam satuan orang, karena dengan melihat migrasi masuk, maka dapat diteliti faktor apa saja yang mempengaruhi perpindahan penduduk ke sebuah provinsi di Indonesia. Faktor-faktor yang diduga mempengaruhi migrasi masuk tersebut adalah Produk Domestik Regional Bruto (PDRB), Upah Minimum Regional (UMR), Tingkat Pengangguran Terbuka (TPT) dan Tingkat Partisipasi Angkatan Kerja (TPAK).

Salah satu indikator penting untuk mengetahui kondisi ekonomi di suatu daerah tertentu adalah dengan melihat nilai dari Produk Domestik Regional Bruto (PDRB) daerah tersebut. Menurut BPS, PDB pada dasarnya merupakan jumlah nilai tambah yang dihasilkan oleh seluruh unit usaha dalam suatu negara tertentu, atau merupakan jumlah nilai barang dan jasa akhir yang dihasilkan oleh seluruh unit ekonomi.

Salah satu faktor penentu migrasi adalah faktor yang berkaitan dengan keuangan, sehingga upah minimum pada daerah tertentu dirasa memiliki daya tarik yang kuat bagi para pelaku migrasi. Kemudian, selain daya tarik dalam keuangan, tingkat kebutuhan tenaga kerja dan ketersediaan lapangan pekerjaan dapat digambarkan dengan melihat seberapa banyak pengangguran disuatu daerah dengan melihat data Tingkat Pengangguran Terbuka (TPT). TPT di indikasikan mempengaruhi keinginan seseorang untuk berpindah ke suatu provinsi, karena jika TPT semakin rendah artinya provinsi tersebut menyerap tenaga kerja dengan baik. Oleh karena itu, penduduk yang melakukan migrasi merasa memiliki harapan yang besar terhadap provinsi tersebut.

Selain TPT, Tingkat Partisipasi Angkatan Kerja (TPAK) juga dianggap memiliki pengaruh terhadap keinginan seseorang untuk berpindah tempat. Angkatan Kerja (TPAK). Menurut BPS, TPAK merupakan persentase jumlah angkatan kerja terhadap penduduk usia kerja yang mengindikasikan besarnya persentase penduduk usia kerja yang aktif secara ekonomi disuatu negara/wilayah. Semakin tinggi TPAK menunjukkan bahwa semakin tinggi pula pasokan tenaga kerja (labour supply) yang tersedia untuk memproduksi barang dan jasa dalam suatu perekonomian.

Data pada penelitian ini memiliki sifat khusus yaitu gabungan antara data runtun waktu (time series) dan data silang (cross section). Setiap variabel yang diamati akan memiliki data per tahun pada setiap provinsi. Maka data per tahun merupakan jenis data runtun waktu (time series) dan per provinsi merupakan data 
silang (cross section). Alat analisis yang digunakan untuk mengolah kedua jenis data tersebut secara bersamaan adalah regresi data panel.

Berdasarkan latar belakang diatas, maka menarik jika membahas "Studi Perpindahan penduduk antar Provinsi di Indonesia dengan Regresi Data Panel”

\section{Tujuan Penelitian}

Dengan melihat dampak dari adanya migrasi masuk terhadap provinsi yang ditinggali sekarang, maka tujuan penelitian adalah untuk melihat bagaimana pengaruh Pendapatan Domestik Regional Bruto (PDRB), Upah Minimum Regional (UMR), Tingkat Pengangguran Terbuka (TPT) dan Tingkat Partisipasi Angkatan Kerja (TPAK) terhadap migrasi masuk pada 33 provinsi di Indonesia.

\section{Metode Penelitian}

Data yang dipakai pada penelitian adalah data migrasi masuk, Pendapatan Domestik Regional Bruto (PDRB), Upah Minimum Regional (UMR), Tingkat Pengangguran Terbuka (TPT) dan Tingkat Partisipasi Angkatan Kerja (TPAK) pada 33 provinsi di Indonesia, yang bersumber dari Badan Pusat Statistik (BPS) pada tahun 2000, 2005, 2010 dan 2015. Hal ini dikarenakan data migrasi masuk didapatkan dari hasil sensus penduduk yang diadakan BPS setiap 5 tahun sekali. Pada penelitian ini, dari 34 provinsi, hanya 33 provinsi yang dipakai, satu provinsi yang tidak dipakai adalah provinsi Kalimantan Utara, dikarenakan provinsi ini baru berdiri pada tahun 2012 .

Alat analisis yang digunakan pada penelitian ini adalah regresi data panel.Tahapan analisis data pada penelitian ini adalah sebagai berikut :

a) Mengumpulkan data

b) Membentuk model Common Effect

c) Membentuk Model Fixed Effect

d) Melakukan uji Chow untuk melihat model yang terbaik untuk data yang digunakan diantara model Common Effect dan model Fixed Effect

e) Setelah memilih, dilakukan kembali pembentukan model yang lain, yaitu Random Effect, agar dapat melakukan pemilihan model terbaik dengan ketiga pilihan model.

f) Melakukan uji Hausman, yang digunakan untuk memilih antara model Fixed Effect dan model Random Effect.

g) Terakhir adalah uji Lagrange Multiplier (LM), yang digunakan untuk memilih antara Common Effect dan Random Effect.

h) Setelah model terbaik dipilih, kemudian melakukan uji asumsi 
klasik, yang digunakan dalam penelitian adalah uji autokorelasi dan uji heterokedastisitas.

i) Setelah melakukan pengujian autokorelasi dan heteroskedastisitas, dan didapatkan bahwa model tersebut masih mengandung autokorelasi dan heteroskedastisitas maka dilakukan perbaikan dengan merubah kebentuk pembobotan (weights).

\section{Regresi Data Panel}

Menurut Ekananda (2015), Regresi data panel adalah regresi yang jenis datanya merupakan gabungan antara data runtun waktu (time series) dan data silang (cross section). Untuk mengestimasi parameter model dengan data panel, menurut Gujarati dan Porter (2012), terdapat beberapa model yang ditawarkan, yaitu yang pertama adalah, jika koefisien tetap antar waktu dan antar individu, atau sering disebut dengan Common Effect. Pendekatan ini tidak memperhatikan dimensi individu dan waktu. Jika konstanta $(\alpha)$ dan koefisien $(\beta)$ akan konstan untuk setiap data runtun waktu dan data silang, maka $\alpha$ dan $\beta$ dapat diestimasi dengan model berikut dengan $N x T$ (banyaknya data panel) pengamatan.

$$
Y_{i t}=\alpha+\beta_{1} X_{1 i t}+\cdots+\beta_{k} X_{k i t}
$$

Dimana,

$Y=$ Variabel terikat (migrasi masuk)

$X=$ Variabel bebas

$i=1,2, \ldots, N, N$ adalah banyaknya data data silang (provinsi)

$t=1,2, \ldots, T, T$ adalah banyaknya data runtun waktu (tahun)

Model pendugaan parameter pada model ini sama dengan model regresi linier biasa yaitu menggunakan metode Ordinary Least Square (OLS) dengan mengabaikan data runtun waktu dan data silang. Model ini mengasumsikan intersep dan slope konstan untuk semua unit data runtun waktu dan data silang (Gujarati dan Porter, 2012)

Model yang kedua yaitu Fixed Effect, dimana menginginkan heterogenitas antar individu subjek dengan memberi setiap entitas nilai intersep tersendiri. Menurut Gujarati dan Porter (2012), model ini meskipun intersepnya berbeda-beda untuk setiap subjek, tetapi tiap intersep tiap entiti tidak berubah seiring waktu. Dengan demikian, maka $\alpha$ dan $\beta$ dapat diestimasi dengan model berikut dengan $N \times T$ pengamatan.

$$
Y_{i t}=\alpha_{i}+\sum_{k=2}^{N} \alpha_{k} D_{k i}+\beta X_{i t}+
$$

Model yang ketiga yaitu Random Effect, dimana teknik ini memperhatikan adanya heterogenitas dari variabel menurut 
individu dan memperhatikan dampak yang berbeda untuk setiap individu (Gujarati dan Porter, 2012). Perbedaan tersebut diakomodasi lewat error. Teknik ini juga memperhitungkan bahwa error mungkin berkorelasi sepanjang data runtun waktu dan data silang. Berikut model dari persamaan tersebut.

$$
Y_{i t}=c_{i}+\beta_{1 i} X_{i t}+\beta_{2 i} X_{i t}+\cdots
$$

Untuk mengetahui model mana yang paling baik untuk digunakan pada data yang dimiliki, terdapat beberapa cara. Teknik yang pertama adalah uji Chow, yaitu teknik yang digunakan untuk memilih model Common Effect atau model Fixed Effect. Teknik yang kedua adalah uji Hausman, yang digunakan untuk memilih antara model Fixed Effect dan Random Effect. Kemudian, teknik yang ketiga adalah uji Lagrange Multiplier (LM), yang digunakan untuk memilih antara Common effect dan Random Effect.

Menurut Gujarati dan Porter (2012) data panel sedikit terjadi kolinearitas antar variabel sehingga sangat kecil kemungkinan terjadi multikolinearitas. Oleh karena itu, asumsi klasik yang digunakan dalam penelitian adalah uji autokorelasi dan uji heterokedastisitas. Menurut Pusakasari (2014), pada regresi data panel, umumnya terjadi pemenuhan asumsi uji autokorelasi dan heteroskedastisitas, maka perlu dilakukan perubahan model ke pembobotan Cross Section SUR. Penggunaan pembobotan ini akan menyebabkan koefisien determinasi meningkat jika dibandingkan dengan sebelum terjadi pembobotan pada model.

\section{Pembahasan}

Pengujian regresi data panel dengan memasukkan data ke dalam model Common Effect didapatkan keluaran seperti pada Tabel 1.

Tabel 1. Model Regresi Data Panel

\begin{tabular}{lcl}
\hline \multicolumn{1}{c}{ Model } & $\boldsymbol{R}^{2}$ & p-value \\
\hline Common effect & 0,432955 & 0,000 \\
Fixed effect & 0,922328 & 0,000 \\
Random effect & 0,013798 & 0,696 \\
\hline
\end{tabular}

Hasil yang didapatkan dari keluaran model Common Effect pada Tabel 1 adalah nilai p-value yang kurang dari tingkat signifikansi 0,05 , dengan nilai Koefisien determinasi sebesar 43,3\%. Model Common Effect mengabaikan keragaman provinsi dan tahun yang digunakan dalam data ini, oleh karena itu, masih dirasa kurang. Sehingga dilakukan langkah selanjutnya yaitu model Fixed Effect.

Kemudian, dengan melakukan percobaan pada model Fixed Effect, berdasarkan Tabel 1 didapatkan bahwa model tersebut signifikan dengan Koefisien determinasi sebesar 92,23\%. 
Nilai ini jauh lebih baik dibandingkan dengan nilai pada Common Effect, namun untuk memilih model mana yang paling baik untuk data yang diteliti, harus dilakukan uji lanjutan terlebih dahulu. Langkah selanjutnya sebelum masuk ke dalam perhitungan model Random Effect, maka terlebih dahulu menguji model Common Effect dan Fixed Effect yang telah didapatkan dengan uji Chow.

Tabel 2. Uji Chow

\begin{tabular}{cc}
\hline & p-value \\
\hline Uji Chow & 0,000 \\
\hline
\end{tabular}

Berdasarkan Tabel 2 p-value 0,0000 lebih kecil dari tingkat signifikansi $5 \%$. Oleh karena itu, model yang terpilih adalah model Fixed Effect. Selanjutnya, menganalisis model Random Effect.Dari Tabel 1 dapat dilihat bahwa model Random Effecttidak signifikan

Apabila hanya dilihat secara garis besar dari analisis tersebut, dapat diputuskan bahwa model Random Effecttidak baik untuk dipilih memodelkan data yang diteliti. Namun akan lebih baik jika diuji terlebih dahulu dengan menggunakan uji Hausman, untuk memilih yang terbaik antara model Fixed Effect dan model Random Effect.

Tabel 3. Uji Hausman

\begin{tabular}{cc}
\hline & p-value \\
\hline Uji Hausman & 0,000 \\
\hline
\end{tabular}

Berdasarkan Tabel 3 didapatkan hasil bahwa model yang paling baik adalah model Fixed Effect, karena nilai p-value lebih kecil dari tingkat signifikansi 5\%.

Oleh karena itu, model terbaik yang dipilih adalah model Fixed Effect. Sebelum menginterprestasikan model, maka terlebih dahulu dilakukan uji autokorelasi dan heteroskedastisitas, didapatkan bahwa model tersebut masih mengandung autokorelasi dan heteroskedastisitas. Sehingga perlu diperbaiki dengan merubah kebentuk pembobotan (weights).

Tabel 4. Model Fixed Effect dengan pembobotan (weights)

\begin{tabular}{lcc}
\hline \multicolumn{1}{c}{ Variabel } & Koefisien & p-value \\
\hline konstanta & 153742,9 & 0,0000 \\
TPT & $-4142,550$ & 0,0001 \\
PDRB & $-0,020201$ & 0,6137 \\
UMR & $-1,666095$ & 0,7226 \\
TPAK & 404,0578 & 0,0031 \\
\hline $\boldsymbol{R}^{2}$ & & \\
\hline p-value (F) & 0,898019 & \\
\hline
\end{tabular}

Berdasarkan Tabel 4 didapatkan model Fixed Effect dengan variabel independent yang berpengaruh secara signifikan yaitu Tingkat pengangguran Terbuka (TPT) dan Tingkat Partisipasi Angkatan Kerja (TPAK). Konstanta pada model pun memiliki pengaruh dengan cara penentuan yang sama. Kemudian secara 
bersama-sama keempat variabel independen mempengaruhi migrasi masuk secara signfikan dengan dengan melihat nilai p-value pada Tabel 4 dengan nilai koefisien determinasi sebesar 89,80\%.

Tingkat pengangguran Terbuka (TPT) memiliki korelasi negatif terhadap migrasi masuk. Hal ini dikarenakan semakin kecil nilai TPT maka akan semakin baik bagi sebuah provinsi, karena dapat diartikan penyerapan tenaga kerja di provinsi tersebut baik. Inilah yang mneyebabkan timbulnya ketertarikan untuk berpindah ke provinsi tersebut. Oleh karena itu, semakin kecil TPT maka akan semakin tinggi migrasi masuknya.

Sedangkan pada Tingkat Partisipasi Angkatan Kerja (TPAK) memiliki korelasi positif terhadap migrasi masuk. Semakin tinggi TPAK pada suatu provinsi maka akan semakin tinggi juga migrasi masuknya. Hal ini diduga karena semakin tinggi partisipasi angkatan kerja pada suatu wilayah memberikan kesan positif dan menarik untuk dijadikan tempat untuk mencari penghidupan, sehingga menambah migrasi masuk pada wilayah tersebut.

PDRB dan UMR tidak berpengaruh secara signifikan, hal ini diduga dikarenakan tujuan masyarakat untuk memilih tempat tujuan untuk brmigrasi bukanlah berapa PDRB daerah tersebut ataupun berapa UMR di tempat tujuan, selain karena ketidaktauan, juga keterbatasan mereka untuk mencari informasi tersebut. Hal ini memang bertolak belakang dengan hasil dari beberapa pengamatan bahwa migrasi dipengaruhi oleh faktor keuangan. Masyarakat Indonesia yang melakukan migrasi memilih daerah tujuan dengan melihat faktor keuangan dari sisi lain, sebagai contoh, seberapa berhasil kerabat mereka yang telah bermigrasi di daerah tujuan, seberapa mudah mereka mencari pekerjaan ataupun melakukan kegiatan usaha, serta alasan lain yang terkait dengan keuangan dalam bentuk kemakmuran yang mereka dapat nilai. Hal ini dapat menggambarkan pula bahwa tingkat pendidikan dari individu yang bermigrasi mempengaruhi bagaimana mereka menilai faktor-faktor yang dipilih untuk berpindah ke suatu daerah.

Setelah dilakukan pengujian tersebut, maka dapat ditentukan model pada masing-masing data cross section, karena model yang terpilih adalah model Fixed Effect. Hal ini dikarenakan pada model Fixed Effect memiliki nilai intersep yang berbeda-beda untuk setiap subjek, tetapi tiap intersep tiap entiti tidak berubah seiring waktu. Model migrasi masuk pada masing-masing provinsi seperti yang ditampilkan pada Tabel 5. 
Tabel 5. Model Migrasi Masuk untuk 33 Provinsi di Indonesia

\begin{tabular}{|c|c|}
\hline Provinsi & Model Migrasi Masuk \\
\hline Aceh & $\begin{array}{l}\text { MIGRASI_ACEH = -111899.690175 + } 153742.944161-4142.55010462^{*} \text { TPT_ACEH + } \\
\text { 404.057792839*TPAK_ACEH }\end{array}$ \\
\hline Sumatera Utara & 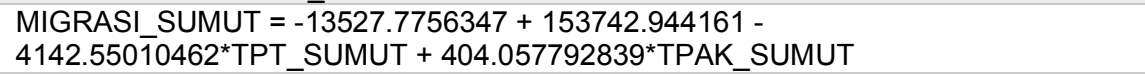 \\
\hline Sumatera Barat & $\begin{array}{l}\text { MIGRASI_SUMBAR }=-23420.3936395+153742.944161- \\
4142.55010462 * T P T \_S U M B A R+404.057792839^{*} \text { TPAK_SUMBAR }\end{array}$ \\
\hline Riau & $\begin{array}{l}\text { MIGRASI_RIAU = 129872.883578 + } 153742.944161-4 \overline{4} 2.55010462 * T P T \_R I A U ~+ \\
\text { 404.057792839*TPAK_RIAU }\end{array}$ \\
\hline Jambi & 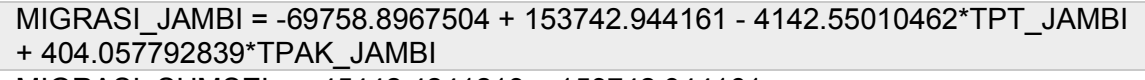 \\
\hline Sumatera Selatan & $\begin{array}{l}\text { MIGRASI_SUMSEL }=-45442.4241213+153742.944161- \\
\text { 4142.55010462*TPT_SUMSEL + 404.057792839*TPAK_SUMSEL }\end{array}$ \\
\hline Bengkulu & $\begin{array}{l}\text { MIGRASI_BENGKUL̄U }=-116316.948859+153742.944 \overline{1} 61- \\
\text { 4142.55010462*TPT_BENGKULU + 404.057792839*TPAK_BENGKULU }\end{array}$ \\
\hline Lampung & $\begin{array}{l}\text { MIGRASI_LAMPUNG }=-50357.0600258+153742.944161- \\
4142.55010462 * \text { TPT_LAMPUNG + 404.057792839*TPAK_LAMPUNG }\end{array}$ \\
\hline $\begin{array}{l}\text { Kepulauan } \\
\text { Bangka Belitung }\end{array}$ & 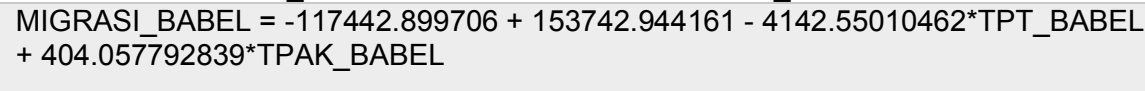 \\
\hline Kepulauan Riau & $\begin{array}{l}\text { MIGRASI_KEPRI = 40595.5244039 + } 153742.944161-4142.55010462 * T P T \_K E P R I+ \\
\text { 404.057792839*TPAK_KEPRI }\end{array}$ \\
\hline DKI Jakarta & $\begin{array}{l}\text { MIGRASI_JAKARTA }=488563.201194+153742.944161- \\
\text { 4142.55010462*TPT_JAKARTA + 404.057792839*TPAK_JAKARTA }\end{array}$ \\
\hline Jawa Barat & $\begin{array}{l}\text { MIGRASI_JABAR }=\overline{7} 82485.031078+153742.944161-\overline{4142.55010462 * T P T \_J A B A R ~} \\
+404.057792839 * \text { TPAK_JABAR }\end{array}$ \\
\hline Jawa Tengah & $\begin{array}{l}\text { MIGRASI_JATENG }=22 \overline{5} 517.755925+153742.944161- \\
4142.55010462 * \text { TPT_JATENG + 404.057792839*TPAK_JATENG }\end{array}$ \\
\hline Yogyakarta & 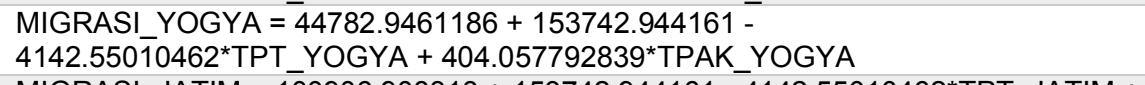 \\
\hline Jawa Timur & $\begin{array}{l}\text { MIGRASI_JATIM = 100906.908313 + } 153742.944161-4142.55010462 * \text { TPT_JATIM + } \\
\text { 404.057792839*TPAK_JATIM }\end{array}$ \\
\hline Banten & $\begin{array}{l}\text { MIGRASI_BANTEN }=\overline{2} 97177.172306+153742.944161- \\
4142.55010462 * T P T \text { BANTEN }+404.057792839^{*} \text { TPAK_BANTEN }\end{array}$ \\
\hline Bali & $\begin{array}{l}\text { MIGRASI_BALI }=-6 \overline{76} 48.0553916+153742.944161-4 \overline{14} 2.55010462 * T P T \_B A L I+ \\
404.057792839^{*} \text { TPAK_BALI }\end{array}$ \\
\hline $\begin{array}{l}\text { Nusa Tenggara } \\
\text { Barat }\end{array}$ & $\begin{array}{l}\text { MIGRASI_NTB }=-979 \overline{9} 5.5089762+153742.944161-4142.55010462 * T P T \_N T B+ \\
404.057792839 * T P A K \_N T B\end{array}$ \\
\hline $\begin{array}{l}\text { Nusa Tenggara } \\
\text { Timur }\end{array}$ & $\begin{array}{l}\text { MIGRASI_NTT }=-113706.678127+153742.944161-4142.55010462 * T P T \_N T T+ \\
\text { 404.057792839*TPAK_NTT }\end{array}$ \\
\hline Kalimantan Barat & $\begin{array}{l}\text { MIGRASI_KALBAR }=-123020.620371+153742.944161- \\
4142.55010462^{*} \text { TPT_KALBAR }+404.057792839^{*} \text { TPAK_KALBAR }\end{array}$ \\
\hline $\begin{array}{l}\text { Kalimantan } \\
\text { Tengah }\end{array}$ & $\begin{array}{l}\text { MIGRASI_KALTENG }{ }^{-}=-73169.2121282+153742.9441 \overline{1} 1- \\
4142.55010462 *{ }^{*} P T \_K A L T E N G+404.057792839 * \text { TPAK_KALTENG }\end{array}$ \\
\hline $\begin{array}{l}\text { Kalimantan } \\
\text { Selatan }\end{array}$ & $\begin{array}{l}\text { MIGRASI_KALSEL }=-72319.1787865+153742.944161- \\
4142.55010462 * T P T \_K A L S E L+404.057792839^{*} \text { TPAK_KALSEL }\end{array}$ \\
\hline $\begin{array}{l}\text { Kalimantan } \\
\text { Timur }\end{array}$ & 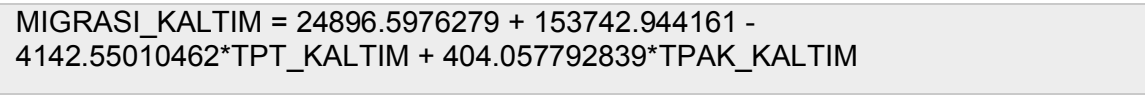 \\
\hline Sulawesi Utara & 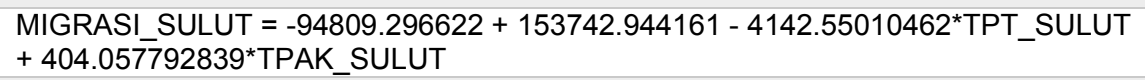 \\
\hline Sulawesi Tengah & $\begin{array}{l}\text { MIGRASI_SULTENG }=-\overline{9} 4336.2754141+153742.944161- \\
4142.55010462 * T P T \text { SULTENG }+404.057792839^{*} \text { TPAK_SULTENG }\end{array}$ \\
\hline Sulawesi Selatan & $\begin{array}{l}\text { MIGRASI_SULSEL }=-27170.6553204+153742.944161- \\
4142.55010462^{*} \mathrm{TPT} \text {-SULSEL }+404.057792839^{*} \text { TPAK_SULSEL }\end{array}$ \\
\hline $\begin{array}{l}\text { Sulawesi } \\
\text { Tenggara }\end{array}$ & $\begin{array}{l}\text { MIGRASI_SULTENGGA }=-89224.5355888+153742.9 \overline{4} 4161- \\
4142.55010462 * T P T \text { SULTENGGA + 404.057792839*TPAK_SULTENGGA }\end{array}$ \\
\hline Gorontalo & MIGRASI_GORONTALO = -133410.177736 + 153742.944161 - \\
\hline
\end{tabular}

The Study of In-Migration between Provinces in Indonesia by Panel Data Regression 


\begin{tabular}{|c|c|}
\hline & 4142.55010462*TPT_GORONTALO + 404.057792839*TPAK_GORONTALO \\
\hline Sulawesi Barat & $\begin{array}{l}\text { MIGRASI_SULBAR }=-126365.570732+153742.944161- \\
4142.55010462 * \text { TPT_SULBAR }+404.057792839^{*} \text { TPAK_SULBAR }\end{array}$ \\
\hline Maluku & $\begin{array}{l}\text { MIGRASI_MALUKU }=-119663.205405+153742.94416 \overline{1}- \\
4142.55010462^{*} \text { TPT_MALUKU + 404.057792839*TPAK_MALUKU }\end{array}$ \\
\hline Maluku Utara & $\begin{array}{l}\text { MIGRASI_MALUT }=-132629.15986+153742.944161-\overline{4} 142.55010462 * T P T \text { MALUT } \\
+404.057792839 * \text { TPAK MALUT }\end{array}$ \\
\hline Papua Barat & $\begin{array}{l}\text { MIGRASI_PAPBAR }=-1 \overline{1} 2441.179232+153742.944161- \\
4142.55010462^{*} \text { TPT_PAPBAR }+404.057792839^{*} \text { TPAK_PAPBAR }\end{array}$ \\
\hline Papua & $\begin{array}{l}\text { MIGRASI_PAPUA }=-108722.621941+153742.944161- \\
4142.55010462 * \text { TPT_PAPUA }+404.057792839^{*} \text { TPAK_PAPUA }\end{array}$ \\
\hline
\end{tabular}

Berdasarkan Tabel 5 didapatkan 33 model terbaik untuk masing-masing provinsi di Indonesia dengan konstanta yang berbeda-beda pada masing-masing provinsi.

\section{Kesimpulan}

Pola migrasi masuk di Indonesia lebih baik di modelkan melalui Fixed Effect sehingga didapatkan 33 model untuk 33 provinsi. Variabel yang berpengaruh terhadap migrasi masuk dengan model Fixed Effect adalah Tingkat pengangguran Terbuka (TPT) dan Tingkat Partisipasi Angkatan Kerja (TPAK). Tingkat pengangguran Terbuka (TPT) memiliki korelasi negatif terhadap migrasi masuk, semakin rendah TPT maka akan semakin tinggi migrasi masuknya sedangkan Tingkat Partisipasi Angkatan Kerja
(TPAK) memiliki korelasi positif terhadap migrasi masuk. Semakin tinggi TPAK pada suatu provinsi maka akan semakin tinggi juga migrasi masuknya. 


\section{Appendix A. Grafik Pola Migrasi Masuk 33 Provinsi di Indonesia}
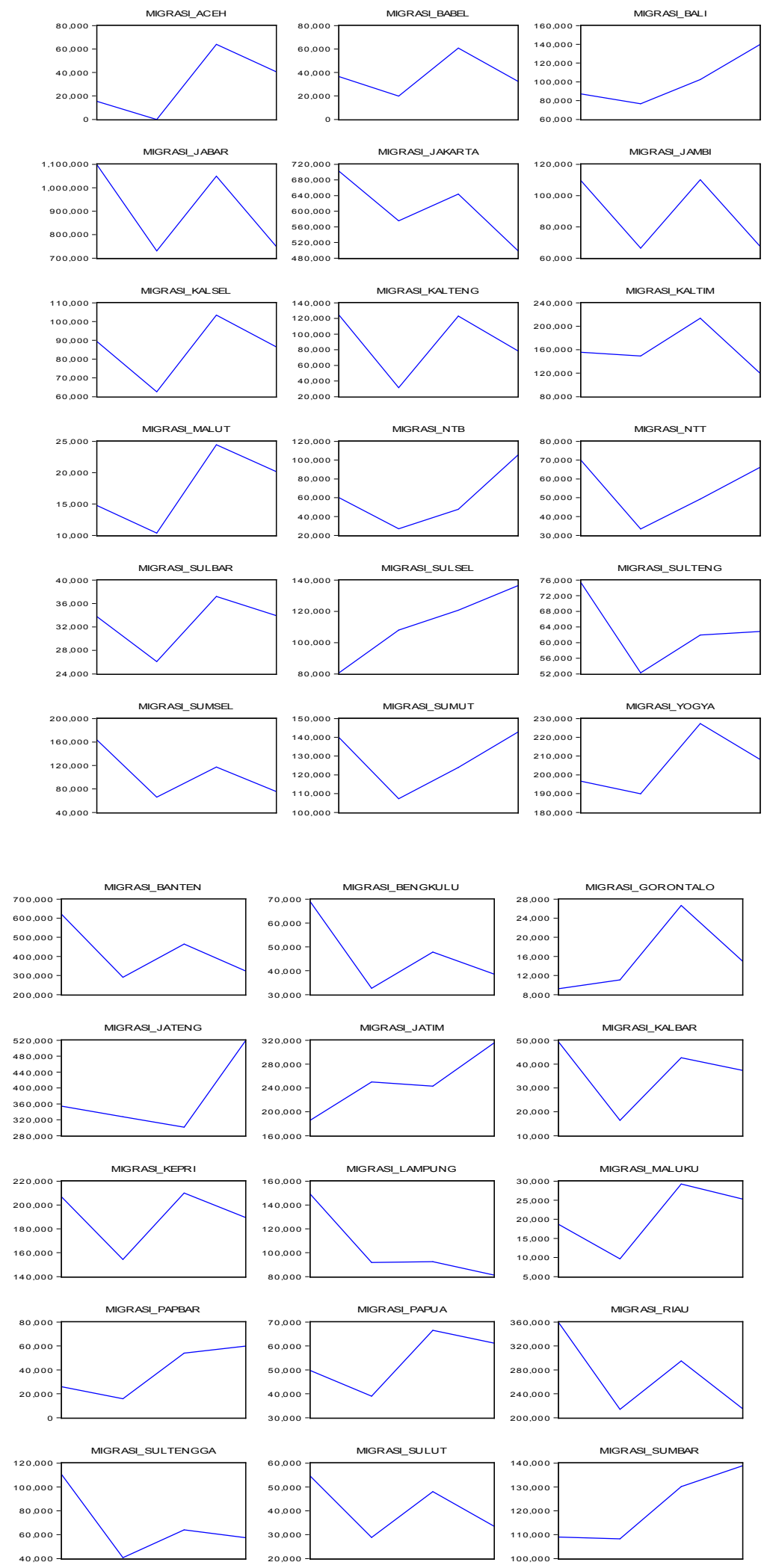

The Study of In-Migration between Provinces in Indonesia by Panel Data Regression 


\section{Pustaka}

Bălă, RM dan Prada, EM., 2014, Migration and Private Consumption in Europe : a Panel Data Analysis, $7^{\text {th }}$ International Conference on Applied Statistics, Procedia Economics and Finance 10, 2014, 141-149.

Badan Pusat Statistik (BPS), http://www.bps.go.id/ Diakses tanggal 17 Januari 2016.

Ekananda, M., 2015, Ekonometrika Dasar untuk Penelitian di Bidang Ekonomi, Sosial dan Bisnis, Penerbit Mitra Wacana Media, Jakarta.

Gujarati, D dan Porter, D., 2012,DasarDasar Ekonometrika Edisi 5, Penerbit Salemba Empat, Jakarta.

Jennissen, RPW., 2003, Economic Determinants of net International Migration in Western Europe, Europian Journal of Population, 19, 171-198.

Pusakasari, A., 2014, Regresi Panel dengan metode Weighted Cross Section SUR pada data pengamatan Gross Domestic Product dengan Heteroskedastisitas dan Korelasi antar Individu (Cross-Section Correlation), Jurnal Mahasiswa
Statistik, Universitas Brawijaya, Vol 2, No 6, 2014, 477-480.

Simanulang, E., Silaen, F \& Budiani, S., 2012, Pola Migrasi dan Pembangunan Ekonomi antar Provinsi di Indonesia, Program Studi Pascasarjana Kajian Kependudukan dan Ketenagakerjaan, Universitas Indonesia, Jakarta. 